Available online at website :

http://uinjkt.ac.id /index.php/elementar

Elementar: Jurnal Pendidikan Dasar, 1(1), 2021, 264-281

\title{
Pengaruh Penggunaan QUIZIZZ Terhadap Motivasi dan Hasil Belajar pada Pembelajaran Jarak Jauh Siswa Sekolah Dasar
}

\author{
Ade Irma Febriyanty ${ }^{1)}$, Tri Suryaningsih ${ }^{2)}$, Zikri Neni Iska ${ }^{3)}$ \\ Program Studi Pendidikan Guru Madrasah Ibtidaiyah, UIN Syarif Hidayatullah Jakarta \\ Jl. Raya Bojongsari No.55, Bojongsari Baru, Kec. Bojongsari, Kota Depok, Jawa Barat \\ E-mail: adeirma.febriyanty17@mhs.uinjkt.ac.id,tri.suryaningsih@uinjkt.ac.ic, zikri.neni@uinjkt.ac.id
}

\section{Corresponding Author: \\ Ade Irma Febriyanty \\ Submit: 24 Desember 2021 \\ Revisi: 30 Desember 2021 \\ Approve: 31 Desember 2021}

Pengutipan: Ade Irma Febriyanty, dkk. (2021). Pengaruh Penggunaan QUIZIZZ Terhadap Motivasi dan Hasil Belajar pada Pembelajaran Jarak Jauh Siswa Sekolah Dasar. Elementar (Elementary of Tarbiyab): Jurnal Pendidikan Dasar, 1(2), 2021, 264-281. elementar.v1i2. 23811.

\section{Abstract}

This study aims to determine the effect of using Quirizi. on the motivation and learning outcomes of 6th grade students at SDN Semanan 08 Pagi Jakarta Barat distance learning mathematics in 2021. This study uses a quantitative method with a Pre-Experimental (One Group PretestPosttest) design, with a sample of 23 students. Data were collected using a Learning Motivation questionnaire and multiple-choice Pretest-Posttest questions using Quiziz: The results of this study indicate that: a) there is an influence between the use of Quizizz. on the students' motivation to learn mathematics at SDN Semanan 08 Pagi Jakarta Barat, with the Wilcoxon test results of $\mathrm{Z}$ (count) $>\mathrm{Z}$ (table $)=2.336>1.96$, and the PValue $(0.019)<(0.05)$ where Ha is accepted and Ho is rejected. b) there is no effect between the use of Quirizz. on the mathematics learning outcomes of the students of SDN Semanan 08 Pagi Jakarta Barat, with the Wilcoxon test results of $=0.890 \mathrm{Z}$ (count) (smaller) $<\mathrm{Z}$ (table) of 1.96, and the P-value Value of (0.373) is greater than 0.05. So Ho is accepted and $\mathrm{Ha}$ is rejected.

Keywords: Quiziq: Learning Motivation, Mathematics Learning Outcomes.

\begin{abstract}
Abstrak
Penelitian ini bertujuan untuk mengetahui pengaruh penggunaan Quiziz: terhadap motivasi dan hasil belajar peserta didik kelas 6 SDN Semanan 08 Pagi Jakarta Barat pembelajaran matematika jarak jauh 2021. Penelitian ini menggunakan metode kuantitatif dengan desain Pre-Eksperimental (One Group Pretest-Posttest), dengan sampel 23 peserta didik. Pengambilan data dilakukan dengan menggunakan instrument angket Motivasi Belajar dan soal Pretest-Posttest berupa pilihan ganda menggunakan Quiziq: Hasil penelitian ini menunjukkan bahwa: a) terdapat pengaruh antara penggunaan Quizizz terhadap motivasi belajar matematika peserta didik SDN Semanan 08 Pagi Jakarta Barat, dengan hasil Uji Wilcoxon sebesar $Z_{\text {hitung }}>Z_{\text {tabel }}=2.336>1.96$, dan nilai P-Value $(0.019)<\alpha(0.05)$ dimana Ha diterima dan Ho ditolak. b) tidak terdapat pengaruh antara penggunaan Quirizz terhadap hasil belajar matematika peserta didik SDN Semanan 08 Pagi Jakarta Barat, dengan hasil Uji Wilcoxon sebesar sebesar $=0.890\left(Z_{\text {hitung }}\right)$ (lebih kecil) $<Z_{\text {tabel }}$ sebesar 1.96 , dan nilai P-Value sebesar (0.373) lebih besar $>0.05$. Sehingga Ho diterima dan Ha ditolak. Kata kunci: Quiziz:, Motivasi Belajar, Hasil Belajar Matematika
\end{abstract}





\section{PENDAHULUAN}

Dunia saat ini tengah dikejutkan dengan wabah pandemi corona virus yang muncul pada tahun 2020 di wilayah Wuhan China, semakin lama mulai menyebar ke berbagai Negara. Satu persatu negara mulai terpapar virus tersebut, tak terkecuali Indonesia mulai terpapar pada bulan maret 2020. Pengaruh yang ditimbulkan oleh virus corona, makhluk yang begitu kecil ini tak dapat dipandang sebelah mata.

Dari berbagai aspek kehidupan sedikit demi sedikit mulai berubah pola pelaksanaan dan sistemnya. Pola hidup sehat, memakai masker, mencuci tangan, jaga jarak, menghindari kerumunan, bekerja dari rumah (Work From Home), Lockdown, PSBB, hingga pada ranah pendidikan antisipasi penularan melalui belajar tatap muka, maka diberlakukan keputusan umtuk melakukan pembelajaran jarak jauh (PJJ) dengan berbagai ketentuan yang sudah ditetapkan pihak kemdikbud mulai diberlakukan secara serentak dari Sabang sampai Merauke. Pada tingkat pendidikan dasar hingga pendidikan tingkat strata dan universitas.

Berdasarkan data evaluasi selama pelaksanaan pembelajaran matematika pada bulan Oktober-November 2020 dalam 9 kali pertemuan di Kelas 6 B SDN Semanan 08 Pagi Jakarta Barat didapati beberapa respon peserta didik dari penugasan harian matematika menggunakan paper yang diberikan, didapati beberapa peserta didik tidak merespon penugasan yang diberikan, dan juga ada beberapa peserta didik jarang mengerjakan. Terdapat 3-10 peserta didik tidak mengumpulkan penugasan matematika yang diberikan pada beberapa evaluasi yang dilakukan. hal ini menunjukkan kurangnya antusias motivasi belajar dan motivasi untuk menyelesaikan tugas pada pembelajaran matematika yang dilakukan.

Sedangkan indikator motivasi belajar menurut Sardirman antara lain seperti : Tekun menghadapi tugas, ulet dalam menghadapi kesulitan (tidak mudah putus asa), menunjukkan minat terhadap bermacammacam masalah, lebih senang bekerja mandiri, cepat bosan pada tugas-tugas yang rutin (halhal yang bersifat mekanis, berulang-ulang saja, sehingga kurang kreatif), dapat mempertahankan pendapatnya (kalau sudah yakin terhadap sesuatu), tidak mudah melepaskan hal yang sudah yakin terhadap sesuatu), serta senang mencari dan memecahkan masalah soal-soal (Sardiman, 2004).

Berdasarkan observasi yang dilakukan terdapat indikator motivasi belajar yang belum muncul pada peserta didik kelas 6 B yaitu masih kurangnya ketekunan dalam pengerjaan tugas karena masih terdapat 3-10 yang tidak mengumpulkan tugas dan juga menggambarkan kurang menunjukkan minat pada masalah dan soal-soal yang diberikan. Serta dampak lainnya dari kurangnya ketekunan dalam pengerjaan tugas adalah terhadap hasil belajar peserta didik. Peserta didik yang tidak mengumpulkan tugas maka hasil belajarnya pun akan kurang terutama pada penilaian harian.

Menurunnya motivasi belajar bukan hanya terjadi di Jakarta saja, sama halnya dialami pula oleh SD di wilayah Trenggalek (Rendra Handy Abdillah, 2020), ditemukan masalah pada kedisiplinan peserta didik dalam 
mengumpulkan hasil kerja (tugasnya), juga masih terdapat peserta didik yang tidak mengumpulkan tugasnya. Selain itu di Purbalingga (Wahyu Andhika Putri dkk, 2020) juga ditemukan masalah terkait turunnya motivasi belajar ditemukan tugas peserta didik yang diberikan pada peserta didik menumpuk sehinga menyelesaikan tugas, ketidakpahaman peserta didik terhadap materi karena dijelaskan secara online juga menjadi penyebab menurunya motivasi belajar di Purbalingga tersebut. Oleh karena itu, penurunan motivasi belajar yang dapat berdampak pada hasil belajar ketika pandemi segera perlu diatasi dan dicari solusinya.

Salah satu solusi untuk mengatasi masalah penurunan motivasi belajar adalah dengan menggunakan Quizirz dimana dalam beberapa kesempatan dicantumkan dalam RPP Pandemi. Akan tetapi, sering sekali ditemui guru yang belum paham dalam penggunaanya, sehingga akhirnya kembali pada sistem penilaian konvensional menggunakan tulis tangan.

Dalam penelitian $\mathrm{N}$ Nazali $\mathrm{dkk}$ mendapatkan hasil bahwa motivasi intinsik dan ekstrinsik para siswa berada pada tingkat yang sedang setelah menerapkan pendekatan gamifikasi. Sementara hasil tes inferensi menggunakan beberapa analisis $44 \%$ dari perbedaan dalam intrinsik para siswa motivasi dapat diprediksi dan 63\% dari dalam motivasi ekstrinsik siswa (N Razali dkk, 2020).

Sedangkan menurut Halimatus Solikah penggunaan Quiziž menunjukkan adanya perbedaan signifikan pada motivasi dan hasil belajar pada siswa kelas eksperimen dan kontrol, sehingga dapat disimpulkan bahwa terdapat pengaruh positif penggunaan interaktif Quizizz terhadap motivasi dan hasil belajar siswa pada materi teks persuasive (Halimatus Solikah, 2020). Dari hasil penelitian tersebut menjadi salah satu alasan peneliti menggunakan Quirizz pada penelitian yang akan dilakukan. karena Quirizz. berdasarkan data tersebut diharapkan mampu meningkatkan motivasi dan hasil belajar peserta didik.

Motivasi belajar sangat penting dimiliki peserta didik dimasa pandemi saat ini, untuk tetap mempertahankan kemauan dalam melakukan pembelajaran, yang akan berdampak baik dengan hasil belajar. Salah satu faktor internal yang mempengaruhi hasil belajar adalah Motivasi. (Endang Sri Wahyuningsih, 2012). Menurut Purwanto menyatakan bahwa motivasi adalah segala sesuatu yang mendorong seseorang untuk bertindak melakukan sesuatu. Menurut Djamarah motivasi adalah perubahan energi di dalam pribadi seseorang yang ditandai dengan timbulnya afektif (perasaan) dan reaksi untuk mencapai tujuan tertentu (Endang Titik Lestari, 2020).

Menurut Syaiful Bahri Djamarah (Djamarah, 2011) mengemukakan beberapa prinsip motivasi belajar, diantaranya: 1) Motivasi sebagai dasar penggerak yang mendorong aktivitas belajar, 2) Motivasi intrinsik lebih utama daripada motivasi ekstrinsik dalam belajar, 3) Motivasi berupa pujian lebih baik dari pada hukuman, 4) Motivasi berhubungan erat dengan kebutuhan dalam belajar, dan 5) Motivasi dapat memupuk optimis dalam belajar.

Menurut Dimyati dan Muldjono faktor-faktor yang dapat mempengaruhi Motivasi Belajar adalah sebagai berikut: 1) 
Cita-cita atau aspirasi Peserta didik, 2) Kemampuan Peserta didik, 3) Kondisi Peserta didik, 4) Kondisi lingkungan Peserta didik, 5) Unsur-unsur dinamis dalam belajar, 6) Upaya guru dalam mengajarkan Peserta didik

Dalam pembelajaran jarak jauh mengharuskan pembelajaran setiap harinya menggunakan media elektronik. Baik dalam pembelajaran maupun penilaian. Salah satu media penilaian yang dapat digunakan adalah Quiziz:

Menurut Purba dalam Rahmi Ramdhani, Quirizzadalah aplikasi pendidikan berbasis game, yang membawa aktivitas multi pemain ke ruang kelas dan membuatnya di kelas latihan interaktif dan menyenangkan (Rahmi Ramdhani dkk, 2020).

Sedangkan dalam Tony Suhartatik mengatakan Quizizz adalah sebuah web tool untuk membuat permainan kuis interaktif untuk digunakan dalam, pembelajaran di kelas misalnya saja untuk Penilaian Harian (PH), Penilaian Tengah Semester (PTS), dan Penilaian Akhir Semester (PAS) (Tony Suhartatik, 2020).

Quizizz menurut Yana dalam Lusiana, kelebihan antara lain sebagai berikut: 1) Lebih efisien disebabkan tanpa memakai kertas; 2) Lebih efektif serta praktis saat merekam jawaban peserta didik secara otomatis, serta langsung terhitung melalui Microsoft Excel; 3) Tidak menimbulkan kebosanan, lengkap dengan gambar yang memiliki warna serta bunyi. (Lusiana, 2020).

\section{METODE}

Penelitian ini menggunakan penelitian kuantitatif, metode Eksperimen yang digunakan dalam bentuk Pre Experiment design, menggunakan desain penelitian One Group Pretest -Posttest Design (Sugiyono, 2017).

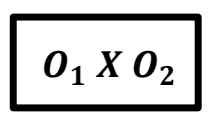

$\boldsymbol{O}_{\mathbf{1}}$ : Nilai Pretest (sebelum diberi perlakuan)

$\boldsymbol{O}_{\mathbf{2}}$ : Nilai posttest (sesudah diberi perlakuan) Penjelasan dari desain ini adalah terdapat satu kelas yang diberikan Pretest $\left(\boldsymbol{O}_{\mathbf{1}}\right)$ lalu diberikan treatment atau perlakuan (X) dan selanjutnya posttest $\left(\boldsymbol{O}_{\mathbf{2}}\right)$.

Penelitian ini dilakukan di SDN Semanan 08 Pagi Jakarta Barat dengan populasinya adalah seluruh siswa kelas VI B berjumlah 30, dengan sampel yang diambil secara simple random sampling dalam satu kelas yaitu kelas 6B sebanyak 23 siswa.

Teknik pengumpulan data dalam penelitian ini didapat dari penyebaran kuesioner sebelum dan sesudah menggunakan Quizizz. sebanyak 35 butir pernyataan dan pemberian Assesment Pretest-Posttest sebanyak 10 soal. Data kuantitatif yang didapatkan kemudian dianalisis dengan menggunakan uji prasyarat dan uji hipotesis beda rata-rata serta pengujian Tingkat Capaian Responden (TCR).

Untuk menguji validitas alat ukur, secara keseluruhan dengan cara mengkorelasikan seiap butir alat ukur dengan skor total yang merupakan jumlah tiap skor butir, dengan rumus Product Momennt.

Setelah melakukan uji validitas menggunakan SPSS Versi 25 didapatkan hasil 23 dari 35 butir pernyataan valid dan 12 tidak valid. Sedangkan untuk butir soal Pretest-posttest 10 soal valid. 
Uji Reliabilitas dilakukan terhadap item-item yang sudah teruji kevalidannya, sehingga item yang tidak valid tidak diikutsertakan. Metode yang sangat populer untuk mencari reliabilitas instrumen menggunakan rumus alpha $\alpha$. Dalam Wibowo dalam Ivan Fanani Qomusuddin mengatakan bahwa indikator pengukuran reliabilitas dibagi menjadi 3 bagian, jika nilai alpha siatas 0,8 dianggap baik, jika 0,6 - 0,799 dianggap dierima, sedangkan jika kurang dari 0,6 maka dianggap mempunyai reliabilitas kurang baik (Ivan Fanani Qomusuddin, 2019).

$\alpha=\frac{k}{k-1}\left[1-\frac{\sum S^{2} j}{S^{2} x}\right]$

Keterangan :

$\alpha=$ Koefisien reliabilitas alpha

$k=$ jumlah item

$S j \quad=$ Varians responden untuk tema I

$S x=$ jumlah varians skor total

Hasil uji reabilitas soal Pretest-posttest menggunakan SPSS Versi 25 adalah 0.680 reliabel. Kemudian hasil uji reabilitas Angket Motivasi Belajar menggunakan SPSS Versi 25 adalah 0.917 reliabel.

Setelah melakukan uji validitas dan uji reliabelitas terhadap instrument penelitian, dilanjutkan dengan melakukan pengujian kesukaran dan daya pembeda pada butir soal Pretest-posttest. Uji tes kesukaran butir ini dimaksudkan untuk menentukan apakah butir tes tergolong mudah sedang, atau sukar bagi siswa yang akan diukur sehingga tes benarbenar dapat menggambarkan kemampuan yang dimiliki siswa (I Putu Ade Andre Payadnya dkk, 2018).

Interpretasi indeks kesukaran soal mengacu pada pendapat Arikunto dalam Ajat
Rukajat memberikan penafsiran terhadap angka indeks kesukaran item butir soal sebagai berikut (Ajat Rukajat, 2018).

\begin{tabular}{|c|c|c|}
\hline No & Interval & Kriteria \\
\hline 1 & $0,70 \leq \mathrm{P} \leq 1,00$ & Butir Soal Mudah \\
\hline 2 & $0,30 \leq \mathrm{P} \leq 0,70$ & Butir Soal Sedang \\
\hline 3 & $0,00 \leq \mathrm{P} \leq 0,30$ & Butir Soal Sukar \\
\hline
\end{tabular}

Dari hasil uji kesukaran terdapa 3 soal kategori mudah, 6 soal kategori sedang, dan 1 soal kategori sukar.

Analisis daya beda butir merupakan pengkajian butir-butir instrument yang bertujuan untuk mengetahui kesanggupan butir untuk membedakan peserta tes yang tergolong mampu dengan peserta tes yang tergolong tidak mampu.

Untuk menghitung daya pembeda butir instrumen digunakan rumus sebagai berikut:

$D P=\frac{J B_{A}-J B_{B}}{J S_{A}}$

Keterangan :

$J B_{A}$ : Jumlah peserta kelompok atas yang menjawab dengan benar

$J B_{B}$ : Jumlah peserta kelompok bawah yang menjawab dengan benar

$J S_{A}$ : Jumlah seluruh peserta kelompok atas/bawah (I Putu Ade Andre Payadnya dkk, 2018).

Pembagian daya pembeda bersasarkan kriteria baik atau buruk tidaknya daya beda suatu item menurut Arikunto dalam Ofianto dan Tri Zahra Ningsih adalah sebagai berikut (Ofianto dkk, 2021):

\section{\begin{tabular}{|l|l|}
\hline Kriteria & Indeks Daya Pembeda \\
\hline
\end{tabular}}




\begin{tabular}{|l|l|}
\hline Jelek & $0,00-0,19$ \\
\hline Cukup & $0,20-0,39$ \\
\hline Baik & $0,40-0,69$ \\
\hline Baik Sekali & $0,70-1,00$ \\
\hline $\begin{array}{l}\text { Semuanya tidak } \\
\text { baik soal harus } \\
\text { diganti }\end{array}$ & Negatis $(-)$ \\
\hline
\end{tabular}

Hasil uji daya pembeda mendapatkan hasil yaitu: 1 soal berkategori jelek, 8 soal berkategori cukup, dan 1 soal berkategori baik. Sehingga dalam penelitian ini digunakan seluruh butir soal sebanyak 10 soal.

\section{HASIL DAN PEMBAHASAN}

\section{Hasil}

Tujuan dilakukan penelitian ini adalah untuk membuktikan apakah ada pengaruh penggunaan Quiziz: dalam pembelajaran Matematika materi Statistika (Mean, Median, Modus) terhadap Motivasi dan Hasil Belajar Peserta didik kelas VI B dengan penentuan sampel menggunakan simple random sampling pada satu kelas yaitu sebanyak 23 siswa. Pembelajaran Matematika dilakukan selama 4 kali pertemuan dengan treatment menggunakan Quirizz selama evaluasi harian.

Setelah dilakukan pengambilan data sebelum dan sesudah menggunakan treatment Quirizz didapatkan hasil :

\section{Data Motivasi Belajar}

\section{a. Sebelum Menggunakan Quizizz}

Sebanyak 1 Peserta didik mendapatkan nilai angket sebesar 70, 77, 80, 86, 87, 89, 95, 97, 98, 107, 109, 110. Sebanyak 2 peserta didik mendapatkan nilai angket sebesar 100, dan sebanyak 4 peserta didik mendapatkan nilai angket sebesar 88, sebanyak 5 peserta didik mendapatkan nilai angket sebesar 90 . Dengan skor rata-rata kelas 91,680, skor Minimum 70 dan Maksimum 110.

\section{b. Sesudah Menggunakan Quizizz}

Sesudah dilakukan treatment dapat disimpulkan sebanyak 1 Peserta didik mendapatkan nilai angket sebesar 80 . Sebanyak 2 peserta didik mendapatkan nilai angket sebesar 100, sebanyak 5 peserta didik mendapatkan nilai angket sebesar 110 dan sebanyak 15 peserta didik mendapatkan nilai angket sebesar 90. Dengan skor rata-rata kelas 94,782, skor Minimum 80 dan Maksimum 110.

Berikut ini adalah penyajian data hasil hasil Pengaruh Penggunaan Quizizz terhadap Motivasi Belajar menggunakan angket sebelum dan sesudah dalam bentuk grafik/histogram:

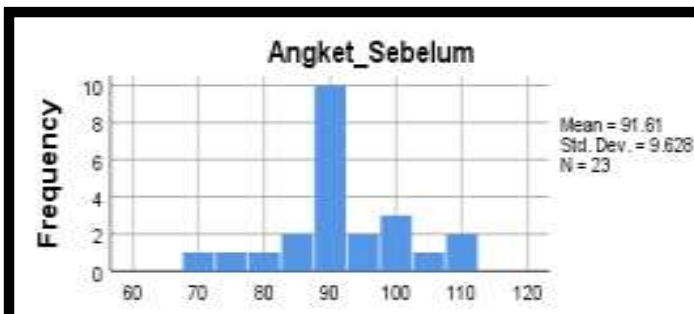

Angket_Sebelum

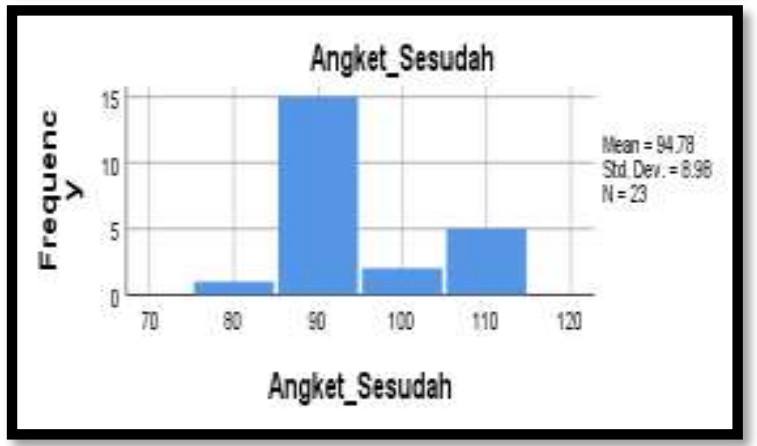

Grafik 1. Histogram Hasil Skor Perolehan Angket Sebelum dan Sesudah Treatment 
2. Data Hasil Belajar

a. Sebelum Menggunakan Quizizz

Sebanyak 2 Peserta didik mendapatkan nilai 30, 3 peserta didik mendapat nilai 40, 2 peserta didik mendapat nilai 50, 4 peserta didik mendapat nilai 60, 1 peserta didik mendapat nilai 70,2 peserta didik mendapat nilai 80, 7 peserta didik mendapat nilai 90, dan 2 peserta didik mendapat nilai 100 , dengan nilai yang mendominasi adalah 90 sebanyak 7 peserta didik. Dengan nilai rata-rata 68,69; Nilai Minimum 30 dan Maksimum 100.

\section{b. Sesudah Menggunakan Quizizz}

Sebanyak 1 Peserta didik mendapatkan nilai 20, 2 peserta didik mendapat nilai 30, 1 peserta didik mendapat nilai 40, 1 peserta didik mendapat nilai 50, 2 peserta didik mendapat nilai 60,5 peserta didik mendapat nilai 70,1 peserta didik mendapat nilai 80 , dan 8 peserta didik mendapat nilai 90, dan 2 peserta didik mendapat nilai 100. Sedangkan nilai yang mendominasi masih sama seperti sebelum treatment yaitu 90, hanya saja pada sesudah treatment. Ini terdapat penambahan sebanyak 8 peserta didik. Dengan nilai rata-rata 71,30 ; Nilai Minimum 20 dan Nilai Maksimum 100.

Berikut ini adalah penyajian data Pengaruh Penggunaan Quizizz terhadap Hasil Belajar peserta didik sebelum dan sesudah melakukan treatment dalam bentuk grafik/histogram:
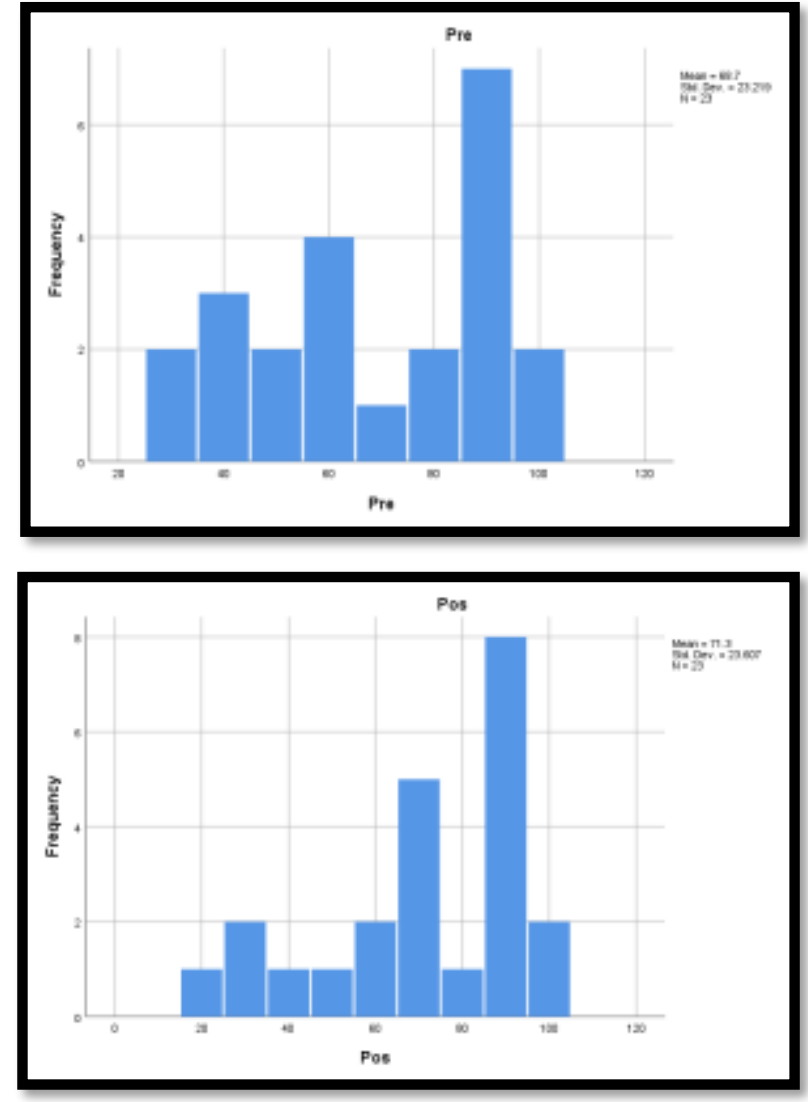

Grafik 2. Histogram Perolehan Hasil Belajar Matematika Sebelum dan

Sesudah Treatment

pengulian Normalltas menggunakan sros Versi 25 :

Tabel 1.

Data Hasil Uji Normalitas Angket dan Soal

\begin{tabular}{|c|c|c|c|}
\hline No & Variabel & $\begin{array}{l}\text { Asymp- } \\
\text { sig } \\
\text { (2-tailed) }\end{array}$ & Keterangan \\
\hline \multirow{6}{*}{1} & Pretest & .020 & Tidak \\
\hline & Hasil & & Normal \\
\hline & Belajar & & \\
\hline & Postest & & Tidak \\
\hline & Hasil & .007 & Normal \\
\hline & Belajar & & \\
\hline \multirow{3}{*}{2} & Angket & .196 & Normal \\
\hline & Sebelum & & \\
\hline & $\begin{array}{l}\text { Angket } \\
\text { Sesudah }\end{array}$ & 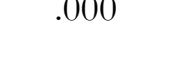 & Tidak \\
\hline
\end{tabular}


Berdasarkan tabel data uji normalitas tersebut dapat diketahui bahwa hanya satu data yang dalam penelitian ini berdistribusi normal pada data angket Pretest dengan nilai sig $0.196>0.05$. Sedangkan yang lainnya tidak normal dengan nilai sig $0.020,0.007,0.000<$ 0.05. Sehingga terdapat perubahan pada uji hipotesis data yng akan dilakukan, bukan lagi menggunakan uji dengan Parametrik melainkan menggunakan uji Non-Parametrik.

Berikut ini adalah hasil dari pengujian Homogenitas menggunakan SPSS Versi 25 :

Tabel 2.

Data Hasil Uji Homogenitas Angket dan Soal

\begin{tabular}{clcc}
\hline No & Variabel & $\begin{array}{c}\text { Asymp-sig } \\
\text { (2-tailed) }\end{array}$ & Keterangan \\
\hline 1 & $\begin{array}{l}\text { Pretest- } \\
\text { Postest Hasil }\end{array}$ & .707 & Homogen \\
& $\begin{array}{l}\text { Belajar } \\
\text { Sebelum- } \\
\text { Sesudah } \\
\text { Angket }\end{array}$ & .427 & Homogen \\
& & \\
\hline
\end{tabular}

Berdasarkan tabel data uji normalitas tersebut dapat diketahui bahwa data PretestPostest pada soal dan Sebelum-Sesudah angket yang diguakan dalam penelitian ini adalah homogen dengan nilai sig 0,707 dan 0,915 > 0,05 .

Sebagaimana salah satu syarat uji $\mathrm{T}$ berpasangan (Paired T Test) dalam buku Febri Endra dikatakan bahwa kedua kelompok data harus berdistribusi normal (Febri Endra Budi Setyawan, 2017). Sehingga dalam pengujian hipotesis penelitian ini yaitu dengan alternatif menggunakan uji non-paremetrik. Dalam buku dikatakan bahwa ketika salah satu syarat dari uji Paired tidak dapat terpenuh, seperti :Data bertipe Nominal atau Ordinal; Data bertipe Interval atau Rasio, namun tidak berdistribusi normal. Maka uji Paired harus diganti dengan uji non paramerik yakni Uji Wilcoxon (Singgih Santoso, 2006).

Berikut ini adalah hasil Uji Wilcoxon $\mathrm{X}$ terhadap Y1 dan Y2 menggunakan SPSS Versi 25:

\section{a. Uji Hipotesis Pengaruh Quizizz terhadap Motivasi Belajar \\ Tabel 3. \\ Data Hasil Uji Hipotesis Motivasi Belaiar}

\begin{tabular}{lr}
\hline \multicolumn{2}{c}{ Test Statisticsa } \\
\hline \multicolumn{3}{c}{$\begin{array}{r}\text { Angket_Postest - } \\
\text { Angket_Pretest }\end{array}$} \\
\hline Z & $-2.336 \mathrm{~b}$ \\
Asymp. Sig. (2-tailed) & .019 \\
a. Wilcoxon Signed Ranks Test & \\
b. Based on negative ranks. & \\
\hline
\end{tabular}

Kriteria uji Wilcoxon Ho ditolak, $\mathrm{Ha}$ diterima jika $Z_{\text {hitung }}>Z_{\text {tabel }}$. Ho diterima dan Ha ditolak jika $Z_{\text {hitung }}<Z_{\text {tabel }}$. atau Ho ditolak dan Ha diterima apabila P-Value < $\alpha$ (0.05). Ho diterima dan Ha ditolak jika PValue $>\alpha(0.05)$.

Berdasarkan data tabel perhitungan Uji Wilcoxon pada Variabel Terikat Motivasi Belajar didapatkan hasil $Z_{\text {hitung }}$ sebesar 0.065 . Sedangkan nilai $Z_{\text {tabel }}$ didapat dari mencari nilai $\mathrm{P}=1-\alpha / 2=1-0,05 / 2=1-0.025=$ 0.975 . Selanjutnya melihat pada tabel $\mathrm{Z}$ positif mencari nilai 0.975 , berada di sisi kiri 1.9 dan sisi atas 0.06, maka $Z_{\text {tabel }}=$ nilai sisi kiri + nilai sisi atas $=$ $+0.06=1.96$.

Maka penarikan kesimpulan Uji Wilcoxon ini adalah $Z_{\text {hitungl }}>Z_{\text {tabel }}=$ $2.336>1.96$, dimana Ho ditolak dan $\mathrm{Ha}$ 
diterima. Atau jika P-Value $(0.019)<\alpha(0.05)$. Sehingga terdapat kenaikan pada nilai rata-rata hasil angket Motivasi belajar, setelah melakukan uji data hipotesis didapatkan hasil bahwa terdapat pengaruh penggunaan Quizizz terhadap motivasi belajar peserta didik Kelas 6B SDN Semanan 08 Pagi Jakarta Barat.

\section{b. Uji Hipotesis Pengaruh Quizizz terhadap Hasil Belajar}

Tabel 4.

Data Hasil Uji Hipotesis Hasil Belajar

\begin{tabular}{cr}
\hline \multicolumn{2}{c}{ Test Statistics $^{\mathrm{a}}$} \\
\hline \multicolumn{2}{c}{ Pos - Pre } \\
\hline $\mathrm{Z}$ & $-.890^{\mathrm{b}}$ \\
Asymp. Sig. (2-tailed) & .373 \\
a. Wilcoxon Signed Ranks Test \\
b. Based on negative ranks.
\end{tabular}

Kriteria uji Wilcoxon Ho ditolak, Ha diterima jika $Z_{\text {hitung }}>Z_{\text {tabel }}$. Ho diterima dan Ha ditolak jika $Z_{\text {hitung }}<Z_{\text {tabel }}$. atau Ho ditolak dan Ha diterima apabila P-Value < $\alpha$ (0.05). Ho diterima dan Ha ditolak jika PValue $>\alpha$ (0.05). Berdasarkan data tabel perhitungan Uji Wilcoxon pada Variabel Terikat Hasil Belajar dengan $Z_{\text {hitung }}=$ 1.96 adalah sebagai berikut.

Penarikan kesimpulan Uji Wilcoxon ini adalah $Z_{\text {tabel }}<Z_{\text {tabel }}=0.890<1.96$, dimana Ho diterima dan Ha ditolak. Atau jika P-Value (0.373) $>\alpha$ (0.05). Sehingga meskipun terdapat kenaikan pada nilai ratarata hasil belajar, namun nilai tidak mengalami kenaikan signifikan dan setelah melakukan uji data hipotesis didapatkan hasil bahwa tidak terdapat pengaruh penggunaan Quizizz. terhadap hasil belajar peserta didik Kelas 6B SDN Semanan 08 Pagi Jakarta Barat.

\section{Pembahasan Penelitian}

\section{Motivasi Belajar}

Setelah memberikan angket Motivasi Belajar sebelum dan sesudah dilakukan treatment menggunakan Quizizz didapatkan hasil skor angket 23 responden adalah sebagai berikut:

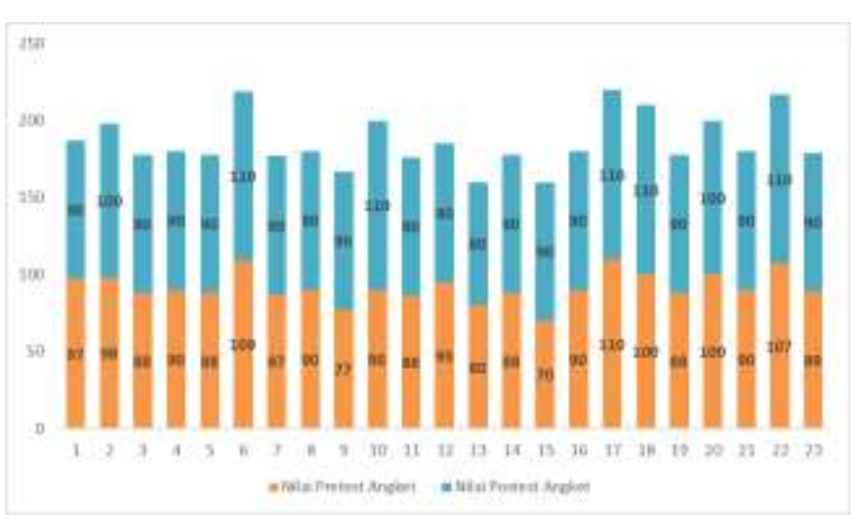

\section{Grafik 3.}

\section{Histogram Hasil Skor Angket Motivasi Belajar Sebelum dan Sesudah Treatment}

Berdasarkan rekapan tersebut dapat diketahui bahwa 14 peserta didik yang mengalami peningkatan hasil belajar setelah menggunakan treatment diantaranya: PD2, PD3, PD5, PD6, PD7, PD9, PD10, PD11, PD14, PD15, PD18, PD19, PD22, PD23. Sedangkan 2 peserta didik yang mengalami penurunan hasil belajar belajar setelah menggunakan treatment diantaranya: PD1, PD12. Dan sisanya adalah 8 peserta didik memiliki nilai yang sama antara sebelum dan sesudah dilakukan treatment diantaranya: PD4, PD8, PD13, PD16, PD17, PD20, PD20, PD21. 
Sedangkan hasil Tingkat Capaian Responden (TCR) pada penelitian ini adalah sebagai berikut:

Menurut Ali dalam Jurnal Zainal Abidin dan Sugeng Purbanwanto (Zinal Abidin dan Sugeng Purbawanto, 2015) menyatakan rumus untuk presentasi tanggapan adalah:

\section{Presentasi tanggapan$$
=\sum \frac{\text { skor data yang diperoleh }}{\sum \text { data total }}
$$

Berikut ini adalah tabel presentasi tanggapan kuesioner :

Tabel 5.

Kriteria Presentasi Tanggapan Kuesioner

\begin{tabular}{lc}
\hline \multicolumn{1}{c}{ Kriteria } & \multicolumn{2}{c}{ Presentase } \\
\hline Sangat Baik & $84 \%<$ skor $<100 \%$ \\
Baik & $68 \%<$ skor $<84 \%$ \\
Kurang & $52 \%<$ skor $<68 \%$ \\
Tidak Baik & $36 \%<$ skor $<52 \%$ \\
Sangat & $0 \%<$ skor $<36 \%$ \\
Tidak Baik & \\
\hline
\end{tabular}

Setelah menyebarkan angket Motivasi Belajar sebelum dan sesudah dilakukan treatment menggunakan Quizizz didapatkan hasil skor TCR pada angket yang disebar kepada 23 responden adalah sebagai berikut:

\section{Hasil Perbandingan Tingkat Capaian Responden}

$\square$ Sebelum Treatment $\square$ Sesudah Treatment

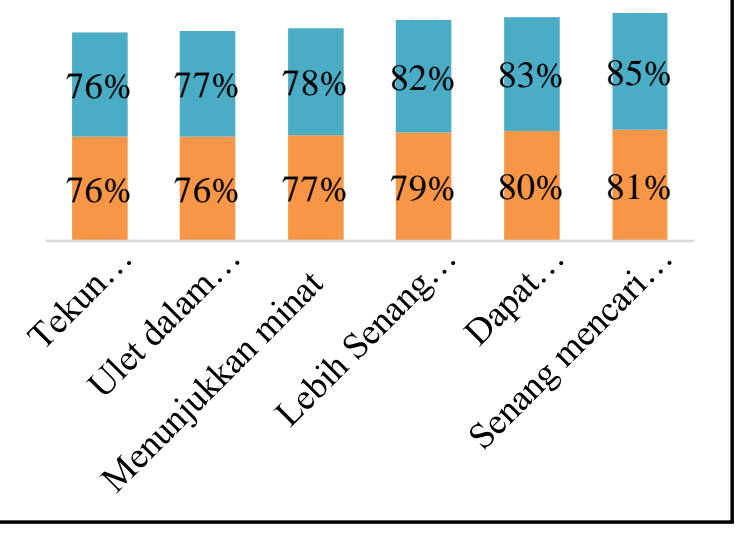

Grafik 3.

Histogram Hasil Tingkat Capaian Responden Angket Motivasi Belajar

Hasil TCR pada Pretest angket terhadap 6 Indikator Motivasi belajar menunjukkan hasil : pada Indikator Tekun dalam menghadapi tugas memperoleh nilai presentase $76 \%$ dengan kriteria Baik; Ulet dalam menghadapi kesulitan memperoleh nilai presentase $76 \%$ dengan kriteria Baik; Menunjukkan minat terhadap berbagai masalah memperoleh nilai presentase $77 \%$ dengan kriteria Baik; Senang bekerja mandiri memperoleh nilai presentase $79 \%$ dengan kriteria Baik; Dapat mempertahankan pendapatnya memperoleh nilai presentase 80\% dengan kriteria Baik; dan Senang mencari atau memecahkan suatu masalah memperoleh nilai presentase $81 \%$ dengan kriteria Baik. Dan nilai TCR terbesar adalah pada indikator Senang mencari atau memecahkan suatu masala dengan presentase $81 \%$. 
Sedangkan Hasil TCR pada Postest angket terhadap 6 Indikator Motivasi belajar menunjukkan hasil : pada Indikator Tekun dalam menghadapi tugas memperoleh nilai presentase $76 \%$ dengan kriteria Baik; Ulet dalam menghadapi kesulitan memperoleh nilai presentase $77 \%$ dengan kriteria Baik; Menunjukkan minat terhadap berbagai masalah memperoleh nilai presentase 78\% dengan kriteria Baik; Senang bekerja mandiri memperoleh nilai presentase $82 \%$ dengan kriteria Baik; Dapat mempertahankan pendapatnya memperoleh nilai presentase 83\% dengan kriteria Baik; dan Senang mencari atau memecahkan suatu masalah memperoleh nilai presentase 85\% dengan kriteria Sangat Baik.

Dan nilai TCR terbesar adalah pada indikator Ulet dalam menghadapi kesulitan, Senang mencari atau memecahkan suatu masalah dengan presentase $85 \%$.

Setelah dilakukan treatment terdapat kenaikan rata-rata TCR pada 4 indikator Motivasi belajar hasil 23 angket responden, akan tetapi peningkatan tidak signifikan dan terdapat 1 hasil TCR pada Indikator dengan nilai tetap jika dibandingkan dengan hasil sebelum treatment.

\section{Hasil Belajar}

Setelah memberikan soal harian sebelum dan sesudah dilakukan treatment menggunakan Quizizz didapatkan hasil adalah sebagai berikut:

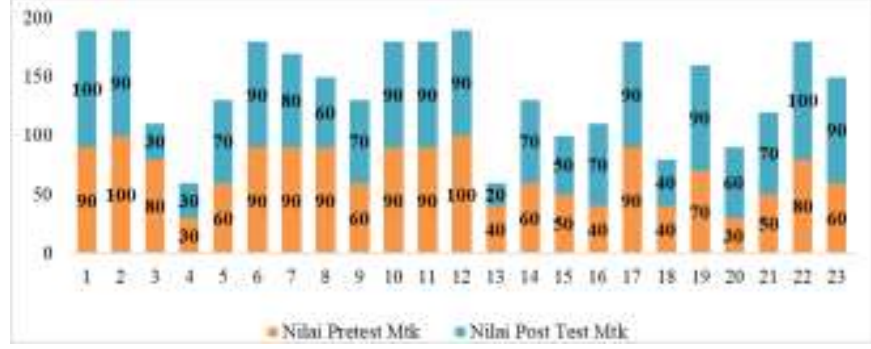

Grafik 4.

Histogram Penilaian Hasil Belajar

Matematika Sebelum dan Sesudah Treatment

Berdasarkan rekapan tersebut dapat diketahui bahwa 11 peserta didik yang mengalami peningkatan hasil belajar setelah menggunakan treatment diantaranya: PD1, PD5, PD9, PD14, PD16, PD19, PD20, PD21, PD22, PD23. Sedangkan 6 peserta didik yang mengalami penurunan hasil belajar belajar setelah menggunakan treatment diantaranya: PD2, PD3, PD7, PD8, PD12, PD13. Dan sisanya adalah 7 peserta didik memiliki nilai yang sama antara sebelum dan sesudah dilakukan treatment diantaranya: PD4, PD6, PD10, PD11, PD15, PD17, PD18.

\section{Pengaruh Penggunaan Quizizz terhadap Motivasi dan Hasil Belajar}

Berdasarkan pengujian prayarat dan uji hipotesis alternatif yang peneliti lakukan mendapatkan hasil sebagai berikut:

\section{a. Pengaruh Quizizz (X) terhadap}

\section{Motivasi Belajar (Y1)}

Kesimpulan Uji Wilcoxon ini adalah $Z_{\text {hitung }}>Z_{\text {tabel }}=2.336>1.96$, dimana Ho diterima dan Ha ditolak. Atau jika P-Value $(0.019)<\alpha(0.05)$. Meskipun 
terdapat kenaikan pada nilai rata-rata hasil belajar, dan nilai tidak mengalami kenaikan signifikan namun, berdasarkan uji Wilcoxon didapat hasil bahwa hipotesis $H_{\mathrm{a}}: \mu_{0} \neq \mu_{a}$ diterima, terdapat perbedaan rata-rata Motivasi belajar setelah menggunakan treatment dan didapatkan hasil bahwa terdapat pengaruh penggunaan Quizizz terhadap Motivasi belajar peserta didik Kelas 6B SDN Semanan 08 Pagi Jakarta Barat.

Dimana $\mathrm{H}_{0}$ : Quizizz. tidak memiliki pengaruh terhadap Motivasi Belajar Peserta Didik Kelas 6 SDN Semanan 08 Pagi Jakarta Barat Jakarta Barat Pembelajaran Jarak Jauh 2021. $\mathrm{H}_{\mathrm{a}}$ : Quiriz: memiliki pengaruh terhadap Motivasi Belajar Peserta Didik Kelas 6 SDN Semanan 08 Pagi Jakarta Barat Jakarta Barat Pembelajaran Jarak Jauh 2021.

Seperti yang dikatakatan Dimyati dan Muldjono (Rinja Efendi dan Delita Gustriani, 2020) terdapat faktor-faktor yang mempengaruhi Motivasi belajar peserta penelitian ini diantara salah satunya seperti: Upaya guru dalam mengajarkan Peserta didik. Upaya yang dimaksud adalah guru mempersiapkan diri dalam pemberian pelajaran seperti dalam pemberian pelajaran, seperti penguasaan materi, cara penyampaian, menarik perhatian peserta didik dan mengevaluasi hasil belajar. Seperti penggunaan Quiriž pada pembelajaran matematika dalam penelitian ini.

Sebagaimana menurut N Nazali dkk (N Razali dkk, 2020) dalam penelitiannya mendapatkan hasil bahwa motivasi intinsik dan ekstrinsik para siswa berada pada tingkat yang sedang setelah menerapkan pendekatan gamifikasi menggunakan Quiziz:

Berdasarkan teori dan hasil penelitian sebelumnya, maka dapat disimpulkan penggunaan Quiriž pada Pembelajaran Matematika dapat meningkatkan atau berpengaruh terhadap Motivasi Belajar, sebagaimana yang dapat dilihat pada Hasil TCR pada Pretest Postest angket terhadap 6 Indikator Motivasi belajar menunjukkan hasil : pada Indikator Tekun dalam menghadapi tugas memperoleh nilai presentase $76 \%-76 \%$ dengan kriteria keduanya Baik; Ulet dalam menghadapi kesulitan memperoleh nilai presentase $76 \%$ - $77 \%$ dengan kriteria keduanya Baik;

Menunjukkan minat terhadap berbagai masalah memperoleh nilai presentase $77 \%$ - 78\% dengan kriteria keduanya Baik; Senang bekerja mandiri memperoleh nilai presentase $79 \%-82 \%$ dengan kriteria keduanya Baik; Dapat mempertahankan pendapatnya memperoleh nilai presentase $80 \%-83 \%$ dengan kriteria keduanya Baik; dan Senang mencari atau memecahkan suatu 
masalah memperoleh nilai presentase 81\% - 85\% dengan kriteria Baik dan Sangat Baik. Dan padnilai TCR terbesar adalah pada indikator Ulet dalam menghadapi kesulitan, Senang mencari atau memecahkan suatu masalah dengan presentase $85 \%$.

\section{b. Pengaruh Quizizz (X) terhadap Hasil} Belajar (Y2)

Berdasarkan data tabel perhitungan Uji Wilcoxon pada Variabel Terikat Hasil Belajar dengan $Z_{\text {hitung }}=1.96$ adalah sebagai berikut: Perhitungan yang dilakukan menggunakan SPSS Verai 25 memberikan hasil $Z_{\text {hitung }}$ sebesar 0.890 , dan P-Value sebesar 0.373. Maka penarikan kesimpulan Uji Wilcoxon adalah $Z_{\text {hitung }}<Z_{\text {tabel }}=0.890<1.96$, atau jika P-Value (0.373) $>\alpha(0.05)$ dimana Ho diterima dan Ha ditolak.

Dimana $\mathrm{H}_{0}$ : Quizizz tidak memiliki pengaruh terhadap Hasil Belajar Peserta Didik Kelas 6 SDN Semanan 08 Pagi Jakarta Barat Jakarta Barat Pembelajaran Jarak Jauh 2021. $\mathrm{H}_{\mathrm{a}}$ : Quizizz memiliki pengaruh terhadap Hasil Belajar Peserta Didik Kelas 6 SDN Semanan 08 Pagi Jakarta Barat Jakarta Barat Pembelajaran Jarak Jauh 2021.

Meskipun terdapat kenaikan pada nilai rata-rata hasil belajar, namun nilai tidak mengalami kenaikan signifikan sehingga hipotesis $H_{0}: \mu_{0}=\mu_{a}$ diterima, tidak ada perbedaan rata-rata Hasil belajar setelah menggunakan treatment dan didapatkan hasil bahwa tidak terdapat pengaruh penggunaan Quiziz: terhadap hasil belajar peserta didik Kelas 6B SDN Semanan 08 Pagi Jakarta Barat.

Dalam pembelajaran online matematika berlangsung, pada saat peneliti menyampaikan materi melalui Grup Whatsapp Peserta didik cukup aktif, namun saat pembelajaran menggunakan aplikasi Google Meet pada pertemuan 4 saat review materi dan diskusi sama seperti pada pertemuan 1 terdapat beberapa peserta didik yang tidak hadir diantaranya setelah ditelusuri hambatan yang dialami yaitu: ada yang terkendala pada jaringan internet, hp dibawa orang tua pergi bekerja, ketiduran, tidak aktif data, membantu menjaga warung keluarga. Sehingga membuat peserta didik tersebut tertinggal pembelajaran tatap muka virtual penjelasan konsep dan diskusi pembelajaran. Sedangkan meraka hanya memahami materi dari penjelasan susulan peneliti melalui grup baik melalui pesan teks ataupun audio.

Beberapa Peserta didik yang terkendala tersebut juga tidak bisa mengikuti Live Quiziz: bersemanaan seperti teman sekelas lainnya. Peserta didik yang terkendala tersebut mengerjakan Quirizz pada malam hari atau keesokan harinya dengan fitur kuis yang sama hanya pengaturan penugasannya saja yang diganti 
menjadi pekerjaan rumah (PR) sehingga dapat diakses sampai batas waktu yang ditentukan. Berdasarkan realita yang terjadi peneliti tidak dapat mengetahui pemahaman konsep peserta didik tersebut dikarenakan tidak mengikuti pertemuan virtual dan berdiskusi, di grup ketika ditanyakan kesulitan atau kendala banyak yang tidak menyampaikannya. Padahal sebagaimana yang disampaikan Wiranda dalam Jurnal Luih Devi Herliandry dkk mengatakan bahwa platform video teleconference yang tersedia gratis seperti Zoom, Google Meet menjadikan pendidik dan peserta didik bertemu dan berinteraksi secara virtual dan kegiatan persentasi (Luih Devi Heliandry dkk, 2020).

Sejalan dengan Wiranda menurut Zhou et al dalam jurnal Luih Devi Heliandry dkk, melengkapi pendapat sebelumnay dengan mengatakan bahwa Presentasi menggunakan Platform tersebut dapat dimanfaatkan sebagai transfer pengetahuan hingga diskusi terkait konten pembelajaran. Namun, dikarenakan terdapat peserta didik yang terkendala, sehingga apa yang disampaikan Wirandan dan Zhou et al tidak dapat terlaksana dengan sebagaimana yang diinginkan (Luih Devi Heliandry dkk, 2020).

Guru juga tidak mengetahui dengan pasti bagaimana internal peserta didik terbentuk selama belajar di rumah. Sebagaimana dalam beberapa faktor pengaruh hasil belajar peserta didik baik dari dalam intrinsik dan ekstrinsik yang tidak dapat diperhatikan secara langsung. Dalam intrinsik seperti yang disampaikan Endang, salah satu faktornya yaitu: cara belajar adalah bagaimana seseorang melaksanakan belajar. Hal ini mencakup : (a) konsentrasi dalam belajar; (b) usaha mempelajari kembali materi yang telah dipelajari; (c) membaca dengan teliti dan berusaha menguasai dengan baik; (d) selalu mencoba menyelesaikan dan berlatih mengerjakan soal. Selain itu faktor eksternal dari lingkungan keluarga juga dapat menjadi faktor penting yang mempengaruhi selama pembelajaran online selama penelitian (Endang Sri Wahyuningsih, 2012).

Kondisi hambatan seperti yang terjadi selama penelitian juga dibahas Asmuni (Asmuni, 2020) dalam jurnalnya memaparkan permasalahan peserta didik pada saat BDR (Belajar Dari Rumah), terdapat 4 faktor dalam peserta didik yang ditemukan sebagai hambatan dalam kegiatan BDR, antara lain: Pertama, Peserta didik kurnag aktif dan tertarik dengan mengikuti pembelajaran daring meskipun akses fasilitas mendukung. Kedua, Peserta didik tidak memiliki perangkat $\mathrm{hp} /$ gadget sebagai Pembelajaran Jarak Jauh (PJJ), jika ada hanya milik ortu mereka dan mendapat giliran setelah orang tua pulang kerja. Ada 
yang pulang di siang hari, sore, bahkan pada malam hari.

Ketiga, Sejumlah Peserta didik tidak memiliki akases internet, sehingga mereka tidak mendapat akses atau menerima informasi PJJ baik menggunakan Whatsapp maupun kelasnya. Keempat Karena sejumlah PJJ sudah berlangsung lama menurut beberapa peserta didik terlalu lama membuat mereka malas dan bosan. Selain itu faktor lainnya disebutkan juga dalam jurnal Asmuni seperti keadaan Orang tua Peserta didik, misalnya pada latar belakang ekonomi dan sosial. Rata rata orang tua bekerja diluar rumah, sehingga nyaris tidak bisa memantau dan mendampingi PJJ, ataupun membimbing langsung saat Peserta didik menghadapi kesulitan.

Berdarkan kedua faktor tersebut yang berada di luar kendali dan variabel penelitian ini, sehingga menjadi penguat penolakan terhadap $\mathrm{Ha}$ penelitian ini. Dimana penggunaan bukanlah satusatunya faktor yang meningkatkan hasil belajar, masih terdapat faktor lainnya yang menjadi penguat diantaranya faktor internal dari peserta didik berupa cara belajar yang juga dapat dihubungkan dengan faktor eksternal dari lingkungan keluarga khususnya orang tua dalam proses pembelajaran online berlangsung.

Maka berdasarkan serangkaian pengujian antara variabel $\mathrm{X}$ dan $\mathrm{Y} 1, \mathrm{X}$ dan
Y2 yang dilakukan dalam penelitian ini, peneliti mendapatkan hasil yang berbeda dari penelitian relevan sebelumnya. Dimana pada penelitian ini Quizizz memiliki pengaruh terhadap Motivasi dan tidak berpengaruh pada Hasil belajar Peserta didik kelas VI dalam Pembelajaran Matematika Jarak Jauh.

\section{SIMPULAN}

Berdasarkan hasil penelitian, analisis data, dan pembahasan yang telah dilakukan pada bab sebelumnya, dapat disimpulkan bahwa terdapat perbedaan rata-rata motivasi belajar sebelum dan setelah menggunakan Quizizz dalam pembelajaran Matematika, sebagaimana pada Peserta didik kelas VIB SDN Semanan 08 Pagi Jakarta Barat Jakarta Barat, dengan nilai Hipotesis menggunakan Uji Wilcoxon pada Variabel Motivasi belajar (Y1) menggunakan SPSS sebesar $Z_{\text {hitung }}>$ $Z_{\text {tabel }}=2.336>1.96$, dimana Ho ditolak dan Ha diterima. Atau jika P-Value (0.019) < $\alpha(0.05)$. Sehingga terdapat kenaikan pada nilai rata-rata hasil angket Motivasi belajar, setelah melakukan uji data hipotesis didapatkan hasil bahwa terdapat pengaruh penggunaan Quizizz terhadap motivasi belajar peserta didik Kelas 6B SDN Semanan 08 Pagi Jakarta Barat Jakarta Barat.

Sedangkan Uji Wilcoxon pada Variabel Hasil belajar (Y1) menggunakan SPSS sebesar $=0.890\left(Z_{\text {hitung }}\right) \quad$ (lebih kecil) $<Z_{\text {tabel }}$ sebesar 1.96, dan nilai P-Value sebesar (0.373) lebih besar $>0.05$. Sehingga 
Ho diterima dan $\mathrm{Ha}$ ditolak sehingga tidak terdapat pengaruh penggunaan Quizizz terhadap Hasil Belajar Peserta didik Kelas VI B SDN Semanan 08 Pagi Jakarta Barat pada Pembelajaran Matematika Jarak Jauh 2021.

\section{REFERENSI}

Abdillah, Rendra Handy. (2020). Efekivitas BION (Bintang Online) dalam Meningkatkan Motivasi Belajar Siswa pada Masa Pandemi Covid 19 di Kelas V SDN 1 Ngembel. Jurnal Pendidikan Dasar Nusantara. Vol.6. No.1.

Putri, Wahyu Andhika dkk. (2020). Penggunaan Audio Visual untuk Meningkatkan Motivasi Belajar Siswa Selama Masa Pandemi Covid-19 pada SDN 1 Serayu Larangan. ABDIPRAJA Jurnal Pengabdian Kepada Masyarakat. Vol 1. No.1.

Razali, N. dkk. Gamification Elements in Quizizz Applications: Evaluating the Impact on Intrinsic and Extrinsic Student's Motivation. IOP Conf. Series: Materials Science and Engineering 917,01202 IOP

Publishingdoi:10.1088/1757899X/917/1/012024. 2020.

Sardiman. (2004). Interaksi \& Motivasi Belajar Mengajar. Jakarta : Raja Grafindo Persada, cet.21.

Solikah, Halimatus. (2020). Pengaruh Penggunaan Pembelajaran Interaktif Quizizz Terhadap Motivasi Dan Hasil Belajar Siswa Pada Materi Teks
Persuasif Kelas Viii Di SMPN 5 Sidoarjo Tahun Pelajaran 2019/2020. Jurnal Mahasiswa UNESA. Vol.7. No.3. Wahyuningsih, Endang Sri. (2012). Model Pembelajaran Mastery Learning Upaya Peningkatan Keaktifan dan Hsil Belajar Siswa. Yogyakarta: Deepublish.

Lestari, Endang Titiki. (2020). Cara Praktis Meningkatkean Motivasi Siswa Sekolah Dasar. Yogyakarta: Deepublish.

Djamarah, Syaiful Bahri. (2011). Psikologi Belajar. Jakarta: Rineka Cipta.

Efendi, Rinja dan Delita Gustriani. (2020). Manajemen Kelas di Sekolab Dasar. Jawa Timur: CV. Penerbit Qiara.

Husamah dkk. (2016). Belajar dan Pembelajaran. Malang: UMM Press.

Prastinyo, Fendika.(2019). Peningkatan Hasil Belajar Peserta Didik Dengan Model Koopratif Jigsaw Pada Materi Di Kelas V SDN Sepanjang 2. Surakarta: CV. Kekata Grup.

Ramdhani, Rahmi dkk. (2020). Platform Pembelajaran Daring: Teori dan Praktik. Yayaysan Kita Menulis.

Suhartatik, Tony. (2020). BEST PRACTICE Implikasi Quizizz. Berbasis Android Terbadap Kualitas Pembelajaran dalam Mencetak. Siswa Berprestasi Di Tingkat Nasional. Ahli Book.

Lusiana. (2020). Penggunaan Aplikasi Online Quizizz Dalam Menganalisis Hasil Tes Kognitif Siswa Pada Materi Energi. SPEJ (Science and Pbsics Education Journal. Volume 4. Nomor 1. 
Siyoto, Sandu dkk. (2015). Dasar Metodologi Penelitian. Yogyakarta: Literasi Medai Publishing.

Sugiyono. (2017). Metode Penelitian Kuantitatif, Kualitatif, dan $\mathrm{R}$ \& $D$. Bandung: Alfabeta.

Unaradjan, Dominikus Dolet. (2019). Metode Penelitian Kuantitatif. Jakarta : Garfindo.

Qomusuddin, Ivan Fanani. (2019). Statistik Pendidikan (Lengkap dengan Aplikasi IBM SPSS Statistik 20.0). Yogyakarta: Deepublish.

Payadnya, I Putu Ade Andre dkk. (2018). Panduan Penelitian Eksperimen Beserta Analisis Statistik dengan SPSS. Sleman: Deepublish.

Rukajat, Ajat. (2018). Pendekatan Penelitian Kuantitatif Quantitative Research Approach. Sleman: Deepublish.

Ofianto dkk. (2021). Assesmen Keterampilan Berpikir Historis (Historical Tbinking). Pamekasan: Duta Publishing.

Setyawan, Febri Endra Budi. (2017). Pengantar Metodologi Penelitian (Statistika Praktis). Siduarjo: Zifatama Jawara.

Santoso, Singgih. (2006). SSBBTI : SPSS Statistik Non-Parametrik+CD. Jkarata: PT. Alex Kompiutindo.

Abidin Zinal dkk. (2015). Pemahaman Siswa Terhadap Pemanfaatan Pembelajaran Berbasis Livewire Pada Mata Pelajaran Teknik Listrik Kelas X Jurusan Video di SMK Negeri 4 Semarang. Edu Elektrika Journal. Vo.4. No.1.
Heliandry, Luih Devi dkk. (2020). Pembelajaran Pada Masa Pandemi Covid-19. Jurnal Teknologi Pendidikan.Vol.22. No. 1.

Asmuni. (2020). Problematika Pembelajaran Daring di Masa Pandemi Covid-19 dan Solusi Pemecahannya. Jurnal Paedagogy: Jurnal Penelitian dan Pengembangan Pendidikan. Vol.7. No.4. 
Pengaruh Penggunaan Quirizz Terhadap Motivasi dan Hasil Belajar Peserta Didik ... 